\title{
Medullary thyroid carcinoma
}

INSERM

\section{Source}

INSERM. (1999). Orphanet: an online rare disease and orphan drug data base. Medullary

thyroid carcinoma. ORPHA:1332

Medullary thyroid carcinoma (MTC) is developed from thyroid C cells that secrete calcitonin (CT). 